\title{
Online Teacher Training Design Based on Learning Management System For TPACK
}

\author{
Sri Hartini ${ }^{1}$, Caraka Putra Bhakti², Shopyan Jepri Kurniawan ${ }^{3}$, Panji Nur Fitri \\ Yanto $^{4}$ \\ ${ }^{1,2,4}$ Guidance and Counseling Deparment, Universitas Ahmad Dahlan, Yogyakarta, Indonesia, \\ ${ }^{3}$ Muhammadiyah 1 Senior High School Yogyakarta, Yogyakarta, Indonesia \\ *sri.hartini@bk.uad.ac.id
}

\begin{abstract}
This paper aims to provide training references for teachers during the Covid19 pandemic and post-pandemic using the Technological Pedagogical Content Knowledge (TPCK) model. In an era that is increasingly advanced and developing, teachers generally have to keep up with existing developments. Technology cannot be separated from an education level. However, the technology used in the educational process must have a strong philosophical and juridical understanding. Besides, existing technology must be accompanied by qualified competencies to create quality education. This study uses a qualitative approach with documentation as a basis for teacher training development based on knowledge technology content. The method used is a literature study. Analysis of research results using national policy analysis.
\end{abstract}

Keywords: Learning Management System; TPACK; Teacher Training

\section{Introduction}

In the globalization era, like now, the world of education has changed a lot and is required to carry out educational reforms. This educational reform is supported by considerable interest in using technological ideas in education [1]. Not only students who must be required to learn, but teachers who are educators also must always improve their competence due to the critical teacher in delivering the educational process. The success of education can cause by the shape of the quality of teachers [2]. Also, it is supported by a situation that requires teachers to transfer of knowledge and transfer of values.

The world is entering the era of industrial revolution 4.0, where all activities carried out by people in every side of human life use information technology, including in the field of education [3]. Where in the era of the Industrial Revolution, 4.0 technology is a must, which means regularly adapting to utilizing this new technology. Of course, many things have been eroded by technology's role, such as replacing human labor with more efficient technology. It is undeniable that the Industrial Revolution 4.0 also made it easy for humans [4][5]. Industrial Revolution 4.0 also influenced by the existence of Covid-19 limited teachers in improving training. This is reinforced by not all students having equal abilities, and of course, it causes various psychological impacts [6] This must also be handled by the teacher so that it can be formulated through training. 
Talking about the field of education, of course, must adjust to the optimal use and be adjusted to the goals of education itself. Education with human beings in it must undoubtedly develop. This is in line with what was stated by [7]. If humans do not develop, the role of humans can be displaced, even though in the era of the industrial revolution, 4.0 humans were given the convenience. Adjustment of technology-based education must, of course, also be accompanied by teacher competence.

A teacher should be able to use innovative and creative learning. With the application of this innovative and creative learning model, it is hoped that teachers can create an efficient learning atmosphere and make it easier for students in the transfer of knowledge [8]. Related documented problems by studying in the 21 st century shows that teachers need to make materials for developing critical thinking students' skills to achieve high metacognition knowledge. These skills allow students to think critically and also have reflective behavior[9].

The development of technology and communication (ICT) has changed various lines of life which make it common for the general public[10]. With these demands, the teacher must find effective learning solutions with a model that can generally be used properly. One of them here uses the use of Learning Management System (LMS) technology and the Technological Pedagogical and Content Knowledge (TPACK) framework, model. Learning Mobile System (LMS) is an internet-based learning aid. The interaction of database files on the LMS was developed by the Sharable Content Object Reference Model (SCORM). LMS application development is carried out by several professional and open-source groups, such as e-learning, Moodle, or Atutor [11].

Meanwhile, Technological Pedagogical and Content Knowledge (TPACK) is knowledge about teachers' ability to use technology based on real character analysis and analysis on pedagogical aspects [12]. TPACK consists of 7 components that influence each other on its constituent components [13]. A teacher's ability to provide learning is undoubtedly greatly influenced by the teacher's TPACK ability [13].

In implementing TPACK, a teacher certainly has to go through intense training to be able to apply TPACK correctly. According to conditions given, offline training cannot be carried out, considering that the Covid-19 case continues to increase. Therefore this paper aims to create a TPACK training design for teachers online using a Learning Management System (LMS).

\section{Literature Review}

\section{A. Teaching and learning}

Learning is one of the basic needs that is important for every human life. Without the human learning process, it will be difficult to survive, because, in the course of the human life journey from infancy to death, the learning process will scientifically continue. This learning process is what will make humans adapt to developing and trying to be better. Learning is a phase of change in all individual behavior that is relatively sedentary due to gaining experience and the results of interactions with the environment that involve cognitive processes [14].

Meanwhile, according to [15] teaching is conveying knowledge to students. Besides, teaching is conveying knowledge to students or students in schools [16]. The conclusion is to transfer the knowledge and experiences that educators have to students. 
The continuity of the teaching process itself means learning. Learning is a combination of human elements, materials, facilities, equipment, and procedures that complement each other and affect the achievement of learning objectives [16]. This means that learning is the continuity of the human learning process with the help of a combination of aspects of science, facilities, and goal-oriented better results. In the learning process at school, of course, there is a teaching and learning process carried out by teachers and students.

\section{B. Framework For Teacher Knowledge For Technology Integration}

In the learning process, the primary resource of knowledge is the knowledge possessed by the teacher. The delivery of knowledge is carried out through the teaching and learning process using the learning system. The learning system is designed to teach science, including knowledge about thinking, student learning, and various subjects [1]. So far, the learning system is still dominant conventionally with activities in the classroom.

Currently we are entering the Industrial Revolution 4.0, where in this era the use of technology has become rampant in terms of the use of human life. Utilization that is based on the use of technology that changes the dimensional order to form combinations that change conditions [3]. The era of Industry 4.0 was marked by the digitalization of information and the extensive use of Artificial Intelligence in various sectors of human life, including in the world of education [3]. Automatically, the usefulness of technology in this era must be utilized to increase the competence of knowledge possessed by teachers. The integration of learning with technology must be done carefully to see the aspects of optimal and efficient use.

\section{Learning Management System (LMS)}

Currently, required learning requires system innovation in a better direction and following the times. Innovative learning processes must concentrate on new results and benefits. On the other hand, innovation must also be carried out without abandoning the old methods, so that the essence of learning is maintained and does not massively erode old cultures. It is even better if the innovation of new teaching methods can provide flexibility to the old way of learning. Of course, this innovation must be supported by the use of media and technology. The new choice of a learning system that has emerged at this time is the learning management system or LMS.

LMS is a package of solutions designed for tracking, delivering, reporting and managing teaching and learning materials, and monitoring the students themselves' progress and interactions. Learning Management System is a software application for teaching and learning activities and online activities (connected to the internet), for example, documentation, administration, making reports of a teaching and learning process activity, and the material being taught is provided online based on the web. It can be accessed via the internet [17]. In essence, LMS is a new digital learning system that automates and virtualizes the teaching and learning process online with flexible functions.

\section{Technological Pedagogial And Content Knowledge (TPACK)}

The framework for TPACK (Technological Pedagogical And Content Knowledge) was originally developed [1] with the basic idea [18] Pedagogical Content Knowledge (PCK). There are three cores of the TPACK framework, namely the primary form of knowledge, namely content knowledge (CK), pedagogical knowledge (Pedagogical Knowledge $=$ PK), and technological knowledge (Technological Knowledge $=$ TK).

Meanwhile, the TPACK framework consists of 7 (seven) different knowledge areas, namely content knowledge (CK) which is the competence of teachers in learning material [1]. TPACK consists of 7 components of knowledge, namely PK,CK, TK, PCK, TCK, TPK, and 
TPACK. TPACK is knowledge needed to make choices in learning about what, who, and how to teach considering the type of technology and available technology sources. TPACK is knowledge that teachers can rely on to develop abilities and 21 st century skills of learners.Learning using the TPACK framework serves to overcome problems faced by students who do not understand the subject matter delivered by educators. Therefore, the existence of the TPACK framework can form learning that is difficult for students to understand with technical assistance so that it is easy to understand[1].

\section{Methodology}

The method used in this paper is to use the literature review method. Here the process of collecting data is done in the form of literature published and written by other authors. Literature used, such as books, articles, and journals [19]. Some critical and quality information fro the literature obtained, combined, and combined with strengthening this writing. For this paper, we did several processes of literature review.

The types of data obtained are varied, qualitative, and quantitative. The collected data is selected and sorted according to the study topic. Then the preparation of the paper is based on data that has been prepared logically and systematically. Data analysis techniques are descriptive argumentative. Writing is done by looking at the relevance and synchronization between one data/information, one with other data/information following the topics studied. Then, the conclusion of the paper is made. Conclusions are obtained after referring back to the formulation of the problem, the purpose of writing, and the discussion. The conclusions drawn represent the paper's subject matter and are supported by practical suggestions for further recommendations.

\section{Result and discussion}

\section{E. Teacher Training for TPACK (Technological Pedagogical Content Knowledge)}

Knowledge of pedagogical content is the intersection and interaction between peda-science and content. PCK is consistent with and is the same as [18] conceptual applicable to specific content knowledge. It includes essential knowledge about curriculum content-based teaching and learning, as well as assessment and reporting of that learning. Awareness of students' prior knowledge, alternative teaching strategies in a line, misconceptions related to typical content, how to fabricate links and connections between content-based ideas, and the flexibility that comes from exploring alternative ways of looking at the same idea or problem, and much more, are all expressions of knowledge of pedagogical content and essential for teaching effect.

Using TPACK is used to develop teacher knowledge that is integrated with technology. For example, if you are interested in integrating learning using food technology, the main source can be used via the internet, you can add graphics and data, with spreadsheet software. In contrast, another may choose to help their students find the data pattern represented by the slope of the sine wave as it is constructed and transformed dynamically with a calculator chart.

So that 22 hours are arranged to conduct teacher training with the TPACK framework using the seven frameworks in TPACK, including the following: 
Table 1. Material Design Training Activities

\begin{tabular}{lll}
\hline Sesion Activity & Material Activity & $\begin{array}{c}\text { Duration } \\
\text { activities }\end{array}$ \\
First Sesion & Post Test & 2 hours \\
& Technological Knowledge & 2 hours \\
& Pedagogical Knowledge & 2 hours \\
& Content Knowledge & 2 hours \\
Second Sesion & Tecnological content knowledge & 2 hours \\
& Pedagogical content knowledge & 2 hours \\
& Technological Pedagogical Knowledge & 2 hours \\
& Tecnological Pedagogical Content Knowledge & 2 hours \\
Third Sesion & Supervsi & 2 hours \\
& Post Test TPACK & 2 hours \\
& Evaluasi TPACK & 2 hours \\
\hline
\end{tabular}

\section{F. Design of Teacher Traing Based on Learning Management System of TPACK}

Training for teachers must always be needed to improve the competence of the teachers themselves. In training used during Covid-19, it must be online based using the Learning Management System in the training that is held must pay attention to the components in training including the assignment process, providing material processes, feedback assignments, and evaluation with the TPACK framework.

The need to improve teacher skills to integrate ICT in learning from various institutions is considered very important [20]. In addition, TPACK has a framework to be implemented that involves some teachers. In fact, most of them have a positive impact, thus helping teachers in making ICT integrated learning. [21][22][23]. So that in training some materials will be used as follows:

Table 2. Design of Training Activities and Training Tasks

\begin{tabular}{|c|c|c|}
\hline Activity Material & Activity Forms & $\begin{array}{l}\text { Task } \\
\text { Assignments }\end{array}$ \\
\hline Post Test & Online Assement & Working on Problems \\
\hline Technological Knowledge & Project based learning & Online Presentastion \\
\hline Pedagogical Knowledge & Project based learning & Presentasi Online \\
\hline Content Knowledge & Project based learning & Presentasi Online \\
\hline $\begin{array}{l}\text { Tecnological content } \\
\text { knowledge }\end{array}$ & Project-based learning & Presentasi Online \\
\hline Pedagogical content knowledge & Project-based learning & Presentasi Online \\
\hline $\begin{array}{l}\text { Technological Pedagogical } \\
\text { Knowledge }\end{array}$ & Project-based learning & Presentasi Online \\
\hline $\begin{array}{l}\text { Tecnological Pedagogical } \\
\text { Content Knowledge }\end{array}$ & Project-based learning & Presentasi Online \\
\hline Supervsi & Group Project & Individual Report \\
\hline Post Test TPACK & Interactive video & Working on problem \\
\hline Evaluasi TPACK & Online Discusion & Online video and chat \\
\hline
\end{tabular}

The teacher training plans and designs described in the previous table are subject to change from time to time. Changes to the activity plan table according to the needs of each school. This training design can be applied at school or home, without being hindered by conditions and situations. 


\section{Conclusion}

As the spirit of education, the teacher is required to demand that he keep up with the times. It is undeniable that the existence of COVID 19 requires teachers always to learn to improve their competence-using a Learning Management system combined with Technological Pedagogical Content Knowledge. So that with a Learning Management system-based training, teachers will be familiar with a combination of technology-based education.

\section{Acknowledgment}

This paper's success and outcome required a lot of guidance and assistance from the Guidance and counseling department Ahmad Dahlan University. We can't finish this paper without a guide of Guidance and counseling department Ahmad Dahlan University. We are grateful after a few months; we can manage to complete this paper.

\section{References}

[1] M. J. Koehler, “Technological Pedagogical Content Knowledge: A Framework for Teacher Knowledge PUNYA MISHRA,” Teach. Coll. Rec., vol. 108, no. 6, hal. 1017-1054, 2006.

[2] I. Akindutire, H. E.-E. Research, dan undefined 2012, "Teacher education in a democratic Nigeria: Challenges and the way forward."

[3] K. Schwab, "The global competitiveness report 2016-2017: insight report. World Economic Forum.," 2016.

[4] E. Nurpitasari, E. A. Arianti, dan P. C. Bhakti, "Model Project Based Learning Untuk Meningkatkan Creative Thinking Siswa di Abstrack Abstrak," Sendika Fkip Uad, vol. II, no. 1, hal. 55-62, 2018.

[5] B. Astuti, R. Lestari, \& C. B.-I. J. of S., dan undefined 2019, "Student DecisionMaking Ability As A Preparation For Facing The Industrial Revolution 4.0," staffnew.uny.ac.id.

[6] C. P. Bhakti dan S. J. \& Kurniawan, "Konsep Psikoedukasi Berbasis Blended Learning bagi Remaja di Masa Pandemi Covid-19," Pros. Semin. Bimbing. dan Konseling, hal. 52-60.

[7] C. P. Ghiffar, M. A. N., Nurisma, E., Kurniasih, C., \& Bhakti, "Model Pembelajaran Berbasis Blended Learning Dalam Meningkatkan Critical Thinking Skills Untuk Menghadapi Era Revolusi Industri 4.0," Pros. Semin. Nas. STKIP Andi Matappa Pangkep, vol. 1, no. 1, hal. 85-94, 2018.

[8] S. Supriyadi, S. Bahri, dan R. S. Waremra, "Kemampuan Technological Pedagogical Content Knowledge (TPACK) Mahasiswa Pada Matakuliah Strategi Belajar Mengajar Fisika," J. Inspirasi Pendidik., vol. 8, no. 2, hal. 1-9, 2018.

[9] I. Maryani, D. R. Putri, S. Urbayatun, Suyatno, dan C. P. Bhakti, "Metacognition and 
integrated-project based learning (I-PjBL) in elementary schools," Univers. J. Educ. Res., vol. 8, no. 3, hal. 1046-1054, 2020.

[10] C. P. Bhakti dan F. A. Rahman, "Android application development of exploration career based on Multiple Intellegence: A model hypothetical," J. Phys. Conf. Ser., vol. 1470, hal. 012043, Feb 2020.

[11] A. F. Daru, "Integrasi Cms Dan Lms Untuk Membangun Web Berbasis E-Learning Dengan Single Login," J. Transform., vol. 11, no. 1, hal. 23, 2013.

[12] M. Sholihah, L. Yuliati, W. W.-J. P. Teori, dan undefined 2016, "Peranan TPACK terhadap Kemampuan Menyusun Perangkat Pembelajaran Calon Guru Fisika dalam Pembelajaran Post-Pack," journal.um.ac.id.

[13] N. Srisawasdi, "The Role of TPACK in Physics Classroom: Case Studies of Preservice Physics Teachers," Procedia - Soc. Behav. Sci., vol. 46, hal. 3235-3243, 2012.

[14] S. . Muhibbin, Psikologi Belajar., Jakarta: PT. Raja Grapindo Persada.

[15] A. M. Sardiman, Interaksi \& motivasi belajar mengajar. Rajagrafindo persada (rajawali pers)., 2004.

[16] Oemar Hamalik, Psikologi Belajar dan Mengajar,. Sinar Baru Algensindo., 2002.

[17] A. Darmawan, "PEMILIHAN SISTEM LEARNING MANAGEMENT SYSTEM (LMS) METODE AHP MENGGUNAKAN CRITERIUM DECISION PLUS 3.0.," Fakt. Exacta, vol. 7, no. 3, hal. 260-270., 2015.

[18] L. S. Shulman, "Those Who Understand: Knowledge Growth in Teaching," Educ. Res., vol. 15, no. 2, hal. 4-14, 1986.

[19] A. Flower, S. C. McDaniel, dan K. Jolivette, "A literature review of research quality and effective practices in alternative education settings," Educ. Treat. Child., vol. 34, no. 4, hal. 489-510, 2011.

[20] Lim, Chai, dan Churchill, "Education Practices: A Capacity- Building Toolkit for Teacher Education Institutions in the Asia-Pacific," Microsoft Partners-in-Learning (Asia-Pacific)., no. June 2015, 2010.

[21] C. Angeli dan N. Valanides, "Preservice elementary teachers as information and communication technology designers: An instructional systems design model based on an expanded view of pedagogical content knowledge," J. Comput. Assist. Learn., vol. 21, no. 4, hal. 292-302, Agu 2005.

[22] A. Jimoyiannis, "Designing and implementing an integrated technological pedagogical science knowledge framework for science teachers professional development," Comput. Educ., vol. 55, no. 3, hal. 1259-1269, 2010.

[23] M. L. Niess, "Preparing Teachers to Teach Science and Mathematics with Technology," in Networking the Learner, Springer US, 2002, hal. 689-697. 